\title{
Making Reliable Persons: Managing Descent and Genealogical Computation in Pakistan
}

\author{
ZEHRA HASHMI
}

\author{
Interdepartmental Program in Anthropology and History, University of \\ Michigan, Ann Arbor, MI, USA
}

INTRODUCTION

My dada (grandfather), contrary to the other family patriarchs, usually looked the other way if a boy turned in poorly calligraphed work. Boys are human, after all. But if by mistake they entered, in place of So-and-So Muhammad Khan, son of So-and-So Muhammad Khan, the name of some other So-and-So Muhammad Khan, and Dada caught it, his wrath was sure to follow. The pens would practically be broken on the offender's fingers. "You pig! What-you're turning my grandfather of the purest pedigree into a bastard!" Back then, we couldn't understand why Dada got so upset over this. All right, we'll correct the mistake. What's there to get so angry about? But now I guess I dimly understand the reason for the severity that characterized our people. Separated from its native land by thousands of miles and several centuries, so that it had nearly forgotten its own native tongue, this Pashtun clan was fighting a losing battle to preserve its lineage, at least on paper (Khan 1998: 245).

\footnotetext{
Acknowledgments: Thank you to the Anthropology and History Reading Group and the Institute for the Humanities at the University of Michigan for their insightful feedback. I am grateful for Thomas Trautmann's and Gillian Feeley-Harnik's incredible expertise and deep engagement with this material. Matthew Hull and William Glover were instrumental in developing the ideas central to this paper. A special thanks to Sher Ali Tareen and Daniel Williford for their brilliant and generous comments, and especially to John Cheney-Lippold for innumerable readings of each draft. I am very appreciative for the close consideration of the anonymous $\mathrm{CSSH}$ reviewers and to David Akin for his exceptional editorial work.
} 
Asad Muhammad Khan's short story Ma'i Dada (1998) subtly and humorously illustrates how genealogical knowledge is central to managing relations between kin, both living and dead. Detailing the laborious and repetitive process of producing genealogical texts, Khan's story highlights the hyper-vigilance against error amongst patriarchs, aimed at stabilizing the genealogical connections required for producing kin-based identity. In doing so, this story is an instructive point of departure for thinking through the anxieties about slippage and legitimacy at the heart of genealogies, in flesh and blood, as well as in textual form.

This article traces the historical relationship between the domain of familial relations and the domain of governance to show how variegations in genealogical thinking and documentation are built into contemporary technologies of rule, in particular, a national identity database in contemporary Pakistan that has a genealogical formation embedded within its very core. I will explore the affect and social meanings attached to genealogies and how they are deployed in bureaucratic settings in efforts to secure descent-based authority and the authenticity of identities. I show how the colonial state in South Asia deployed genealogical expertise for its own purposes, and follow how these practices condition postcolonial capacities for genealogy-based claims to identity. I argue that the capacity to verify an identity and present oneself as a reliable and trustworthy person-especially in order to meet the expectations of an ethno-securitized state - continues to hinge, even in the age of biometric technology, on genealogical success or tragedy: an outcome dependent on the ability to produce evidence of genealogical claims.

Set in colonial India and originally published in Urdu in 1982, Khan's story is an autobiographical account of his family's employee - a figure called Ma'i Dada - who was a master of the family's genealogy but whose own origins remained contested until the end of his life. This story brings into focus how genealogies and the calculations they entail are far from restricted to a hermetically sealed, domestic realm. While Ma'i Dada was officially registered in "police papers, ration cards, state hospital records, and finally in the register of the cemetery" (ibid.: 1) as Abdul Majid Khan Yusufzai-a name signifying his Pashtun identity - the neighborhood dhobis (launderers) had spread rumors that he was from the low Hindu caste of telis (oil pressers). While Ma'i Dada was not a family member, he was considered an expert in matters concerning "pashtuniyat." His insider status in Khan's Pashtun and Muslim family was firmly established; for instance, he freely expressed outrage at the fact that since Pashtun children began to receive an English education, they had failed to

\footnotetext{
${ }^{1}$ Pashtuns, often called "Pathans" in non-Pashtun majority areas, are an ethnic group of various tribes extending across the Durand Line, the current Pakistan and Afghanistan border. See Fredrik Barth (1965) and Akbar Ahmed (1976) for discussions on Pashtunwali, the "way of the Pashtuns" or tribal code of conduct.
} 
commit even a single murder, an obvious sign of their emasculation and degeneration. In moments like the one described at this article's beginning, when children were mandated by family elders to write hundreds of copies of the clan's genealogy, Ma'i Dada would step in and facilitate the learning of genealogies. The urgency in Ma'i Dada's commitment to the cultural integrity and genealogical knowledge of the family was a product of their historical moment, suffused with concerns about the loss of Muslim culture under colonialism. In this context, kinship, lineage, and genealogy acquire an urgent significance since their very survival is at stake.

I follow Khan's emphasis on the high-stakes nature of genealogical knowledge to ask when and how genealogies assume a renewed significance, and to what effect. In this line of inquiry, I also ask who is authorized to make and transmit genealogical knowledge. How do the production, maintenance, and use of genealogies intersect, or misalign, with the broader socio-historical and political milieu they are situated within? Genealogies do not exist untouched in the wild, ready to be picked up and put to use. They are constantly reshaped and rendered by specific persons, genealogical experts like Ma'i Dada, according to a set of both immediate and historical conditions. In the case of the Mirzakhels, the author's diasporic Pashtun sub-clan, Ma'i Dada, as an insideroutsider figure, provides the labor of genealogical maintenance. In other cases, such an outsider role can be taken up by the state, as it makes and thus recasts genealogical information.

Ma'i Dada shows that the method to perfect genealogies required precision, calculation, and embodied practice, a "torment" of copying genealogical tables that was "as mandatory as circumcision" (ibid.: 246). Otherwise, a grandparent could be misrepresented as an uncle down a different lineage, or a paternal uncle could be transformed into a maternal one by "another somewhat remote computation (hisaab)" (ibid.). Genealogical computation is the practice of "calculating" kin ties to produce a relation. For instance, the calculation "my mother's brother is my maternal uncle" is seemingly simple but requires the production of an equivalence that we normalize because we do it all the time. ${ }^{2}$ The manner in which Ma'i Dada reasserted the value of genealogical computation and attached this practice to the very meaning of Pashtun identity foregrounds the intimate relationship between genealogical descent, kinship, and ethnic identity. ${ }^{3}$

While computation may signal operations involving quantities and not qualitative entities like relationships, I follow Khan and the story's translator's use of the term "computation" to describe the practice through which

\footnotetext{
2 See related discussion on the debates surrounding kinship terminology and the "merger of kinship categories," in Trautmann (2001).

3 On genealogy, kinship, and identity formation in relation to gender, nation, and culture, see Ramaswamy (2010), Moore (2003), and Abu-Lughod (1986).
} 
connections are added up (or not) to identify and manage social relations. Computations are essential for making successful genealogical claims, for not only maintaining an existing genealogy but also ensuring the reliability of identities to be grafted into the genealogy down the road. For our purpose, the concept of genealogical computation prefigures the mode in which Pakistan's identity database manages, albeit in automated fashion, descent-based relations. In fact, the historical and cultural connections between domains of governance and kinship shape how the contemporary Pakistani state comes to compute genealogical relations as well as how citizens respond to the state's demands for genealogical records.

As Engseng Ho (2006) and Andrew Shryock (1997) demonstrate, genealogies are far from straightforward representations of lineal descent. Genealogies are difficult to stabilize even when recorded, reproduced, and in some cases standardized by colonial and postcolonial government officials. For instance, Nadav Samin shows how a "genealogical rule of governance" was inaugurated in Saudi Arabia through Aramco and British officials who had vested interests in using lineal descent models of kinship to legitimize territorial incursions (2015: 176). With several modes and motivations for reckoning kinship, the continual reworking and maintenance required by genealogies places them at the heart of the contentious process of producing verifiable and reliable descent-based identities. In particular, the strategic removals, additions, and leakages involved in tracing descent have conditioned the possibilities and the limits of identification by the colonial and postcolonial states in South Asia.

As I will show, the role of genealogical computation in determining and authenticating identity attests to the mutual formation of familial and governmental structures. The role of kinship, and genealogical records in particular, has historically varied across regional administrative systems in South Asia in ways that map onto ethnic distinctions and, crucially, the divergence between "tribal" and "settled" areas in colonial South Asia and now postcolonial Pakistan. Seemingly "exceptional" states of rule, such as in the tribal areas, ${ }^{4}$ demonstrate how genealogical computation operates not only to establish identity but also to de-authenticate it. An ethno-historical comparison between two cases of identity re-verification - one from a settled Pashtun area and the other from a tribal area - shows how these variations and the discrepancies they produce are designed into Pakistan's centralized, databased identification regime as a whole. ${ }^{5}$ The case of tribal Pashtuns thus foregrounds how genealogical knowledge, along with the

\footnotetext{
4 After much political debate and negotiations, the 25th amendment to the Constitution of Pakistan was passed in 2018 to merge the Federally Administered Tribal Areas with the province of Khyber-Pakhtunkhwa (formerly known as the North West Frontier Province).

5 Partha Chatterjee, in his analysis of John Stuart Mill's theory which argued that representative government could not apply to "dependencies" such as India and Ireland, describes how the colonial state relied on a normative structure of rule under which exceptions were not contradictions but rather central to modern regimes of power (2011: 11).
} 
governance practices it is constituted alongside, is as much about exclusion as it is about belonging.

THE NATIONAL DATABASE AND REGISTRATION AUTHORITY AS GENEALOGICAL EXPERT

I was first alerted to the significant role that genealogies played in state operations by a far less amusing figure than Ma'i Dada: Pakistan's former Interior Minister Chaudhary Nisar Ali Khan. In a 2016 press conference, he announced that the National Database and Registration Authority (NADRA), which produces Pakistan's biometric-based national identity card, would be "re-verifying" identity cards as part of a broad national security drive. ${ }^{6}$ In NADRA's terms, this effort to re-verify identity cards was aimed at differentiating non-Pakistanis from Pakistanis.

Earlier in 2014, due to national security concerns surrounding citizenship status and suspicions about Afghans in possession of Pakistani identity cards, many Pashtuns - frequent targets of Pakistan's post 9/11 counter-terrorism and securitization procedures - had already had their identity cards "blocked." A blocked card meant that the card holder's citizenship status was "under verification" according to the notices they received from NADRA. The immediate reason behind the 2016 press conference and the public announcement of a mass identity re-verification campaign was an American drone strike that killed Afghan Taliban leader Mullah Mansoor. Mansoor, an Afghan, was not only killed in Pakistan but was also found to be in possession of a NADRA identity card and a Pakistani passport under the name Wali Ahmed. This incident became a source of considerable international embarrassment for Pakistan. ${ }^{7}$

The minister reported at the press conference that around two hundred thousand "fake" cards had been blocked. He recognized that some "genuine" Pakistani citizens might be affected and said they would be given a chance to appeal their case through NADRA. He listed documents that blocked card holders could show to prove their citizenship. One of them was the shajarah$y i$-nasab, a genealogical chart issued by the revenue department.

NADRA began operations in 2000 by launching a multi-biometric (fingerprint, facial, and iris recognition) electronic identity card. NADRA has registration centers in every major city and in district centers in rural areas where citizens can apply for an identity card. NADRA's significance lies in its ubiquity: the card is used for banking, paying bills, school admissions, acquiring a cell phone chip,

\footnotetext{
6 Associated Press of Pakistan, "Nisar Orders Re-Verification of 180 Million Pakistani Citizens," Dawn, 25 May 2016, https://www.dawn.com/news/1260606 (accessed 26 Mar. 2020).

7 Ilyas M. Khan, "Mullah Mansour: The Trail of Clues after Taliban Leader's Death," BBC News, Islamabad, 24 May 2016, https://www.bbc.com/news/world-asia-36369236 (accessed 26 Mar. 2020).
} 
property transactions, voting, and weapons licenses. Operating on the basis of kin units as well as individuals, NADRA's custom-made software integrates and verifies data, determining who is a Pakistani citizen or changing individuals' and families' statuses from citizen to "alien." 8 Alongside biometric identification technology, NADRA generates links between family members in its database as a means of establishing unique individual identity.

NADRA's identification processes build upon and deploy genealogical practices that preceded it, especially practices that facilitated the process of identifying individuals. The longstanding act of making genealogies and refining genealogical expertise indicate that identity in South Asia could not be grounded in self-proclamations. Rather, identity claims had to be supported through the expertise of genealogical specialists. ${ }^{9}$ Accordingly, NADRA's reliance on genealogical thinking, and kinship more generally, places NADRA in a long line of South Asian genealogical experts. ${ }^{10}$ The secrecy with which these genealogical specialists guard their knowledge, and especially their texts, parallels NADRA's concerns with authenticating identity. ${ }^{11}$ NADRA protects the "right to information" and its records are not accessible to all, but only to specific NADRA officials, and their "patrons"- those who possess an ID card through which they can look up their identity records.

I do not want to overstate this comparison between traditional genealogists and NADRA technicians, but rather to draw a nuanced distinction between NADRA's kinning practices and the genealogical expertise of communities that have been in the trade, so to speak, much longer. NADRA's governance functions are directed at determining individual citizen identity; it does not assemble genealogies in the "deep" sense of tracing origins. ${ }^{12}$ Since NADRA's

\footnotetext{
${ }^{8}$ For a discussion of "citizen" and "alien," and the gray area in between, see Benhabib (2004), and Feldman (2007).

9 Such genealogical specialists often belong to discrete, descent-based communities themselves. In Punjab, for instance, the most prominent groups known for their genealogical expertise were the mirasis. See Rose 1970[1914]; Tandon 1961; and Nayyar 2000.

${ }^{10}$ The colonial state drew upon local individuals and groups well-versed in genealogical knowledge. For example, patwaris (village revenue staff) were re-trained to ensure that genealogical records, among other matters, were kept up to date (Smith 1985). While NADRA does not directly interact with patwaris or genealogical experts such as mirasis, it relies on an infrastructure of genealogical knowledge that is linked to these groups through the colonial period.

11 The need for accurate information about kin relations was a significant factor in NADRA's formation, arguably beyond an obsession with "clean data" motivated by the hubris of technological prowess. Governments have always been preoccupied with the authenticity of genealogies and the falsification of identities, be it now, apparent in NADRA's identification practices, or in the age of precolonial empires and dynastic kings such as the Guptas and the Mughals. See Shah and Shroff 1959.

${ }^{12}$ In South Asia there is a genre of genealogical texts that outline the origins of ethnic and genealogical communities, for example Niamatullah's “The History of the Afghans," (1829), which was originally composed in Persian in the court of the Mughal emperor Jahangir and details the origins of the Afghans as well as chronicles the reign of two Afghan dynasties that ultimately led to the rise of the Mughal Empire. See Khoja 2020, for an account of the nuanced differences between
} 
inauguration in 2000, its database has mapped kinship relations among the citizen population, drawing connections between generations, up to three or four deep. For years before 2000, NADRA has a scanned, digital record of the paperbased "manual" identity card registry set up during the 1970 s. ${ }^{13}$ For verifying ancestral connections prior to the 1970s, NADRA has to draw upon a much older genealogical record which primarily exists in relation to land ownership present in the shajarah-yi-nasab. This document is readily drawn upon through the already existing revenue department's record.

NADRA's turn to this older genealogical record should not surprise us. Genealogies, particularly in their written form, often shape people's sense of who they are (Evans-Pritchard 1969) and, in turn, the states' ability to identify them as such (Shryock 1997: 79). NADRA's decision to verify citizen's identities based on the shajarah-yi-nasab reveals that genealogical relations, and their documentation and verification through instruments such as genealogical tables, have long been under the purview of governments prior to the creation of NADRA. In particular, for collecting long-standing genealogical connections, NADRA calls upon the documentation regimes of other parts of the state, whose administrative apparatus was in large part built by the colonial state in India.

The role of genealogies in the core functions of the colonial state, such as revenue collection, informs how the postcolonial state identifies, but not in entirely predictable ways. The function of revenue collection may no longer be central to postcolonial governments. ${ }^{14}$ Nonetheless, the case of NADRA shows how the Pakistani state continues to draw from a machinery of documentation and registration that was originally targeted at revenue collection and the governance of property relations. The postcolonial state directs these genealogical records and the practices towards other purposes, such as digital identification practices. Conversely, routinized interactions with the state in this mode, involving documents and kin-based identification, shape how citizens respond in encounters with the postcolonial state. In short, a longstanding relationship exists between not only genealogy and identity, but also genealogical identity and structures of rule. ${ }^{15}$

Afghan genealogies, and how they were deployed to make claims to kingship in eighteenth-century South Asia.

${ }^{13}$ My dissertation details the impetus behind Pakistan's first national identity card, which was intiated during Zulfiqar Ali Bhutto's regime in 1973 in the aftermath of a civil war and the creation of Bangladesh (formerly East Pakistan). The dissertation also examines the technological and institutional transition from the earlier "manual" identity registration system to the formation of NADRA in 2000.

${ }^{14}$ See World Bank 1999.

15 As Paul Dresch suggests, genealogy has long been tied to governance concerns. He argues that this "stateless" society, namely tribal organization, was in fact a response to a growing state. Similarly, as I will describe later, in the Pashtun tribal areas, genealogies were essential even as the colonial state saw these areas as being outside the realm of governability (1988). 
While NADRA maps kin networks horizontally between Pakistani citizens, it also draws upon already existing genealogical records through a well-established colonial and postcolonial documentation regime. ${ }^{16}$ The question of who is related to who, or even what makes them related - in other words, kinship — is far more varied in social life than what gets codified as kinship, and even more so than descent in the form of genealogical records. Genealogical records serve a scaffolding function and seek to officialize that which is often slippery and contradictory in the realm of practice ${ }^{17}$ Governments, especially colonial states seeking legitimation, thus lean on genealogical sources for the purpose of tracking, governing, and distinguishing between heterogeneous groups.

The long-debated relationship of kinship to biological relations, not to mention to cultural understandings of human reproduction, has frequently been tied to racializing theories (Fritzsche 2008; Weston 2001). This line of argumentation highlights practices of exclusion and subordination that are often part and parcel of kinned affinities (Edwards and Strathern 2000). When colonial and then postcolonial states use (primarily biological) kinship and genealogical data as the backbone of identification, this process includes some people at the cost of excluding others. The project necessitates discriminating among citizensnational/alien, verifiable/suspect-to authenticate identity. Scholars outlining new approaches to kinship studies have criticized the assumption that kinship organized "simpler," more "traditional" pre-state societies but not modern state societies (McKinnon and Cannell 2013). Kinship clearly continues to inform significant aspects of political and economic life, including inheritance, business, and electoral practices (Yanagisako 2015). Kinship as an organizing force does not disappear in the functions of the modern state but gets embedded within them (Lambek 2011).

Genealogical computation takes on renewed significance as descentbased connections are increasingly embedded within contractual relations, including citizenship, nationality, and relations with the state at large. ${ }^{18}$ As Gillian Feeley-Harnik shows (2013:211), contentions surrounding citizenship involve defining the status of persons, for which ancestry and descent are far from irrelevant concerns. In the context of NADRA, this insight unsettles the assumption that modern state societies have moved in a linear way from status to contract and highlights the mutual formation of familial and governmental

\footnotetext{
${ }^{16}$ Chapter 3 of my dissertation details the technical and social processes that led NADRA to structure its database according to kin relations. This paper will not delve into the details of NADRA's database and instead will focus on how it deploys genealogical records, in particular the shajarah-yinasab.

${ }^{17}$ See Schneider (1984) for a critique of kinship as consanguinity and genealogy as biological descent, and Bouquet (1996) for a discussion of the "visual imperative" of genealogies.

${ }^{18}$ Feminist scholars (Franklin and McKinnon 2011) in the field of kinship studies have worked to dismantle the assumptions of nineteenth-century theorists such as Tönnies (1887), Maine (1861), and Spencer (1893).
} 
structures. ${ }^{19}$ Moreover, NADRA's use of the already existing shajarah-yi$n a s a b$, with its roots in colonial governance, demonstrates how concerns about status, routed through genealogy and kinship, come to determine citizen identity. Thus, the colonial state in India's codification of the genealogical record, particularly in the shajarah-yi-nasab, now directly utilized by NADRA, percolates into notions of citizenship and belonging in postcolonial Pakistan.

\section{GENEALOGICAL COMPUTATION AND GOVERNANCE IN COLONIAL}

PUNJAB AND POSTCOLONIAL PAKISTAN

The shajarah-yi-nasab is a window into the relationship between governance and genealogy across the colonial/postcolonial divide. The colonial state in India deployed it for revenue settlement and the management of property relations. In order to levy revenue, the colonial state had to determine who was responsible for paying it. Thus, it took it upon itself to determine who was entitled to land and how the revenue burden was to be distributed amongst those "rightful shareholders" (Baden-Powell 1892: 85). It became imperative to identify and record community customs to facilitate this process, especially where land was owned jointly, and to ultimately determine who in a given village belonged to the proprietary body. ${ }^{20}$

As Neeladri Bhattacharya argues, "Village and agnatic ties were not always coterminous: village communities were not inevitably tied through common descent" (2018: 286). It was in this context - of collecting revenue while also attempting to maintain (always partially) an "authentic" organization of social relations - that kinship relations and genealogical documentation became most consequential for the colonial state. This is best understood in the colonial official Baden-Powell's own words in Land Systems of British India, where he describes what he understood the shajarah-yi-nasab to be and why it was a document of "utmost importance" for the central task of managing property relations. He explains the function of the genealogical table in relation to the village proprietary body, proposing a mimetic relation between branches of the "tree" and the composition of the village. "From this document we can at once tell the brief history and constitution and form of the village, and how it is divided; its total revenue; the area of each co-sharer's holding, with a reference to the numbers in the list of holdings (to be presently mentioned). This document must be seen to be appreciated" (1892: 564).

19 Grossberg's (1985) important work on the relationship between family and the law in nineteenth-century America shows that the role of kinship in governance is not a question of "backwardness" or an inability to modernize "properly." The mutual formation (and transformation) of the domains of kinship and governance is not exceptional but part of a larger context of governance.

${ }^{20}$ This can be observed in the ethnographic monographs of colonial officials such as Charles Tupper's canonical Punjab Customary Law (1881). 
This document was a complete account of the corporate land-owning group, showing how a given village (and sometimes more) was divided according to the various "branches" of the genealogy. Correspondingly, the shajarah served two distinct purposes for colonial governance. First, by accounting the measure of interest in the estate of each "co-sharer" (ibid.), the shajarah showed who was responsible for paying revenue on each tract of assessed land. Second, given that colonial officials considered the village to be the salient unit of Indian society itself, the shajarah revealed the constitutive and authentic form of the village. The shajarah-yi-nasab, as Baden-Powell described, provided a view into the "history" of the village through the genealogy of its coparceners. He said it was an essential complement to other documents because it gave a sense of how the village ought to be ordered according to kinship as well as genealogical principles considered inherent to the structure and integrity of village India.

Kinship and its documentation continue to play a role in postcolonial technologies of rule. During identity registration, data-entry operators at NADRA centers collect biometric data from individuals, and also request documents such as family members" identity cards or the "b-form" (a document for registering minors under age eighteen), or the presence of a next of kin who can vouch for their relationship with the individual being registered. All applications for identity cards are approved by assistant managers at the NADRA office, and later again at the NADRA headquarters, after which the identity card is printed. By requiring family members' documents or the presence of one family member to vouch for another (through their biometric print) during registration, NADRA integrates biometrics with familial information to establish unique identities.

Those who find themselves "blocked" had received their identity cards after completing the registration process, but now, due to suspicion raised about their citizenship status at a later stage, are asked to re-authenticate their identity through additional documentation and investigation. While NADRA consistently uses kin relations (in this context, the connections between biological relations) to establish identity during this initial registration process, it is in moments when NADRA is compelled to re-authenticate citizen identity that it turns to genealogical materials, including the shajarah-yi-nasab.

NADRA's reliance on the shajarah-yi-nasab reveals an underlying assumption that societies are genealogically organized, and that one way to find out who someone is, is to establish who their ancestors were. To this end, NADRA integrates and draws upon long-standing documentary technologies such as the shajarah-yi-nasab, but also property deeds, especially of ancestral (abayi) lands, reflecting NADRA's need for descent-based evidence) and family registries, to enhance its capacity to verify citizen identities. NADRA's list of supporting documents for cases of re-verification includes land records registered prior to 1978, and also from before 1978, local/domicile certificates, government employment certificates, educational documents, and arms or 
driving licenses or manual national identity cards. ${ }^{21}$ Importantly, this list of documents does not include a foundational identity document: the birth certificate. For even as a birth certificate can verify name, age, and parents, it tells nothing of long-term territorial or descent-based affiliation. By requesting documents from before 1978, NADRA asks the difficult question of who a citizen is based on who their predecessors were, where they lived, and how long they lived there. They attend in their documentation requirements to moments of re-territorialization, such as the formation of Bangladesh in 1971, and large migrations, such as the mass influx of refugees sparked by the Afghan-Soviet war starting in $1978 .^{22}$

In this way, NADRA makes spatial and temporal cuts that determine the kinds of genealogical computations it will accept. ${ }^{23}$ The administrative logic for verification is not solely directed at matching the individual's name with unique bodily characteristics, which biometrics would achieve. Instead, the documentation requested will only be available to those who have belonged to a specific configuration of Pakistani territory during a designated timeframe. The documents requested for identity verification illustrate the desire for territorial clarity. Given that the shajarah-yi-nasab was always directed at identifying a person as co-sharer in land, this is the most robust (and oldest) documentary technology available to NADRA for resolving their problems around pre-1978 identity verification. Yet, it is founded in a normative mode of genealogical reckoning, rooted in ideas of kinship attached to land and government. It relies on the notion that anybody with a shajarah-yi-nasab is indisputably Pakistani, and if not, they are likely mired in the territorial ambiguities that emerged later. This makes exceptional those who have inhabited lands and lived outside these modes of genealogical record keeping. It does not mean that genealogical computation fades in these locations that, contingently enough, are distanced from the centers of documentary production. Genealogies are mediated by specific documents but also extend beyond them into the domain of substances and qualities, such as blood, houses, and truth claims, thereby drawing markers of status, prestige, and trustworthiness into the realm of identification. To explain how this occurs, I turn next to the genealogical labor that people who encounter NADRA must undertake to render reliable and verifiable their identities, and their very sense of personhood.

\footnotetext{
21 During my fieldwork with Pashtun migrants, many of those going through re-verification processes referenced these documents. They are also listed in this news report: Danish Hussain, "Method of Unblocking CNIC can Turn Chaudhry Nisar 'Sikh': PkMAP Minister," Express Tribune, 2 June 2017, https://tribune.com.pk/story/1426049/method-unblocking-cnic-can-turn-chaudhrynisar-sikh-pkmap-minister (last accessed 9 Apr. 2021).

22 On the paradoxes of citizen identity, particularly in relation to documentary evidence, see Das (2019), Torpey (2000), and Petryna and Follis (2015).

23 I draw on Vazira Zamindar's work (2007), which shows how the Indian subcontinent's partition extended beyond the events in 1947 through the creation and enactment of documentary requirements to control the movement of populations across the border.
} 
GENEALOGICAL SUCCESS: THE RELIABLE CITIZEN AND THEIR CLAIM TO BELONGING

"You know that mosque at the corner of this street? The caretaker of that mosque got a letter from NADRA, addressed to me. He was the one who read it out to me. When I heard the words 'your card is temporarily blocked,' I nearly had a heart attack." This was how Gulnar Bibi, a Pashtun woman who lives in an informal settlement in Islamabad, told me that her card had been "blocked"- -she had been placed under "citizen re-verification" by NADRA. She was responding to one of the first questions I asked upon encountering the prevalent phenomena of blocked cards: How did people find out that their card, often still in their physical possession, had been blocked? At the time of our conversation, Gulnar had just returned home from an errand and immediately, carefully, placed her ID card in a steel trunk in her room. She told me that ever since being informed that her card was blocked she had kept it under lock and key in that trunk. "Every time I look at that piece of paper it causes me incredible stress and takes me back to that time when I first heard that news." Gulnar Bibi's perspective and experience illustrate the ways that NADRA's re-verification procedures are entangled with the capacity for genealogical computation. As Gulnar's strategy for authentication shows, this capacity comes to hinge on one's ability to render oneself trustworthy, particularly in the absence of genealogical records.

The process of getting her card unblocked led Gulnar Bibi to navigate a bureaucratic infrastructure beyond NADRA. This included acquiring a shajarah$y i$-nasab from the revenue department, along with a host of other documents, such as her parents' identity cards and property deeds from their ancestral home. At the same time, in her view, her blocked card had put into question her identity as a citizen and as a trustworthy person. She seemed personally offended by the state's suspicion toward her, and sought to correct this by legitimating herself not only through documents but also by presenting herself as an ethical, truthful, and forthright person. According to this logic, as a reliable person, her claims to citizenship would also be more trustworthy. In other words, why would she of all people lie about her identity? That was not the kind of person she was. Gulnar's claims to trustworthiness were built through stories she told, her self-presentation, and her ability to compute her genealogical connections and thereby assert lineage claims.

Gulnar Bibi's concerns about her identity card were entangled with worries about her home - always at risk of demolition - and her anxieties about her kin relations and the documentation of them. Her emphasis on the reliable and honorable aspects of herself were also meant to bolster her position in her community. Gulnar Bibi lives in a small katchi abaadi, an informal settlement, in Islamabad. Katchi abaadis are often termed "encroachments" by city authorities, but since this residential sector began to grow, middle-class people's houses have begun to encroach into this settlement, and they now encircle the katchi abaadi dwellers. Gulnar Bibi is active, confrontational, and loud in her fight 
against city authorities' threats of demolition. She is fond of telling stories about how her name has in the past brought bulldozers to a screeching halt. An important source of her influence is the amount of time she has spent in the hallways and offices of bureaucrats, "getting work done." As for her middle-class neighbors, she shares an electricity line with one of them, in return for which she pays most of the bill. She is forced to be civil but is not shy about confronting them with sharp words when they redirect monsoon water that floods her home.

Gulnar's home, with its precarious location, was an important aspect of her desire to be recognized in an official domain. Over time, I found that she was deeply preoccupied with authentic documentation in general, alongside the problem of legality. "The identity card is important for so many reasons. In fact, I want to show it to them in the Supreme Court during our next hearing for the katchi abaadi case. I will show that the address on my card is of this very place. Exactly this spot where I am standing. See, it says that right here!" Gulnar Bibi thrust her identity card in my hands and pointed emphatically to the address line on the back of the card. In this instance and others, Gulnar Bibi repeatedly argued that her claim to this informal space was bolstered by the fact that the state had recognized it in its most fundamental piece of identification: the NADRA identity card. The address, written out on this particular document, could serve as ultimate proof that the state recognized her claim.

Through the NADRA card, points of verification are built into infrastructural nodes interspersed into everyday life. Its ubiquity speaks to the card's databased quality: the capacity of a seemingly immaterial verification process to materialize in a number of things and settings, from cell phone chips to banks. During the time that the card is "blocked," having it in one's physical possession is only useful to a certain extent. At some checkpoints, showing the card or even a copy of it might help get one through. However, checkpoints can have equipment that lets military personnel or police check the card's unique ID number, which would reveal its blocked status. The fear of this possibility was a deterrent for many blocked card holders, forcing them to take alternative routes or not leave their neighborhoods at all. In addition, banks in Pakistan require a NADRA card to open an account and for ATM transactions for income support payments. ${ }^{24}$ Circa 2013, all Pakistani telecom companies were required to re-verify that cell phone users matched up with individuals who had bought the SIM cards in the first place. This was considered a high priority since cell phones were used to track terrorists and detect future threats. ${ }^{25}$ The NADRA card thus intersects with

\footnotetext{
24 Pakistan State Bank Regulations, Know Your Customer Programme, AML/CFT Regulations for MFBs, "Customer Due Diligence and Anti Money Laundering (M)," http://www.sbp.org.pk/ acd/2018/C2-Annex.pdf (last accessed 9 Apr. 2021).

${ }^{25}$ Associated Press of Pakistan, "SIM to Be Issued after Biometric Verification," Dawn, 29 July 2014, https:/www.dawn.com/news/1122290 (accessed 26 Mar. 2019). Also, see Pakistan Telecommunication Authority's website detailing the role of biometric verification, https://www.pta.gov.pk/ en/biometric-verification (accessed 26 Mar. 2019).
} 
a variety of daily activities. For people like Gulnar, the blocked card did more than obstruct these practical day-to-day activities; it put at risk her ability to inhabit her home and the city. For people like Gulnar, an identity card built on kin and genealogical relations fundamentally shapes their everyday urban lives and their economic and social standing.

The Interior Minister mentioned earlier did not name which ethnic groups were or would be most affected by re-verification. However, it weighed most upon Pakistan's Pashtun population from the Federally Administered Tribal Areas: the province of Khyber Pakhtunkhwa as well as the Pashtun belt of Baluchistan. ${ }^{26}$ Re-verification has also impacted the Burmese and Bengali populations residing in Karachi (Anwar 2013), since they are required to document that not only they, but also their parents were living in West Pakistan prior to the creation of Bangladesh.

For NADRA, this "verification drive" was and continues to be aimed at separating non-Pakistani citizens from Pakistani citizens. There are degrees of blocking based on the different stages of verification. The "suspect" person is notified, as per the NADRA Ordinance of 2000, through a letter sent out to the address on their card. More frequently, I found, people discover their card is blocked at a moment when they try to use it, and this is what prompts them to initiate the verification process. Gulnar Bibi's experiences will reveal this process in more detail, but this generally involves an interview style meeting, commonly referred to as a "board," with the NADRA verification committee. If the card is not cleared at this level, then the case is referred to a District Level or Joint Verification Committee, which includes NADRA personnel as well as officials belonging to the many intelligence agencies. ${ }^{27}$

As one would expect, these board-style verification interviews require card holders to bring with them documentary and other kinds of evidence demonstrating their ties to Pakistan, including the presence of family members. However, reliable evidence involves more than just documents, and often more documents than were required at the time the card was issued. In official settings and beyond, the process of collecting evidence requires familial ties and connections, for everything from procuring documents to gathering family members at the "board" meetings. Ideally, at the end of the process, if all requirements have been met, the card should be unblocked. This is not always the outcome though, and the timeline toward resolution remains rather opaque.

While the experience of blocking varies from person to person, Gulnar Bibi's narrative touches upon many salient aspects of the process of unblocking

\footnotetext{
26 Earlier on during the re-verification program, the NADRA spokesperson claimed that most holders of blocked cards were Afghan refugees. However, those that were in fact Pakistani nationals were "misidentified" as Afghan due to shared ethnicity, namely Pashtun: "100,000 Pakistanis Lose Nationality for Being 'Suspect Aliens,", Dawn, 29 May 2015, https://www.dawn.com/ news/1184905 (last accessed 9 May 2021).

27 See Hussain, "Method of Unblocking."
} 
and its entanglement with genealogical computation. Gulnar's actions to get her card unblocked reveal the ways in which relatedness, both to one's family and to a larger social network (such as the neighborhood), shapes NADRA as an institution and a database.

The aforementioned letter Gulnar Bibi received from NADRA told her to show up in person for an interview, or else the card would be permanently blocked. "Now how would I get there? It is far and expensive. I was also afraid of going there, and so I gathered my paternal uncle and my brothers. We had to take two taxis to get there," she recalled. Already, in Gulnar's mind, having kin members present (with functional identity cards) would add weight to the genealogical claims she planned to make.

Gulnar Bibi expressed surprise at the lack of police or military presence at the NADRA office. For Gulnar Bibi, her experience and understanding of the board rendered it an interrogation focused on the creation of evidence. A significant portion of the scholarship on biometric identification (Abraham 2018; Gates 2011; Magnet 2011) focuses on how biometric technology centers the body, as evidentiary truth, over other sources. Yet when asked what evidence Gulnar Bibi has for the identity card she possesses, even when it is situated within one of the largest centralized biometric-based databases, she must present documents that identify not only herself but her father, mother, and brothers. In particular, Gulnar presented copies of her grandparents' manual identity cards from the first identity registration process undertaken by Zulfikar Ali Bhutto's government between 1973 and 1977. NADRA officials present enquired after Rekhmina Gul, her daughter and only child possessing a card at that time, and Gulnar Bibi informed them of Rekhmina's sick son. "I told them that Rekhmina is in the hospital with her sick child. You are welcome to go check whether she is there right now or not." Every word mattered in order to demonstrate that she was a truthful citizen.

Gulnar responded to NADRA officials' questions about her family by emphatically stating that they were Sayyid. She posed to me the rhetorical question, "Who are Sayyids?" and then exclaimed, "The descendants of the Prophet!" further emphasizing her position as a reliable, and indeed a respectable and most of all known person, and thus unsuspicious. ${ }^{28}$ She elaborated with some specifics: Her grandfather roamed the area around Peshawar on horseback and was a healer, especially for women who could not have children. After a few seconds pause, she added: "Then I also told them that my uncle was a butcher." Moving on from the family history, the interviewers asked for proof that Gulnar Bibi was from Peshawar, and specifically from an area called Gul Bahar, since her parents' documents were from that area. "The man interviewing me told me, 'You have to get the papers of the house and a letter from the tehsil District

28 For a discussion on "prophetic genealogy" and "genealogical prophecy," see Ho (2006: 130-32). 
Superintendent and from the Union Councilor.' ${ }^{29}$ I asked, 'What if the man who is there now doesn't know me, because I left when I was very young?"' They responded that she would find a way; they would surely know someone in common in the neighborhood. NADRA officials wanted to know both her genealogical connections and whether they were rooted territorially in the place she claimed. They handed her a sheet of paper listing all of the documents that were required of her, including a shajarah-yi-nasab that would delineate her family tree in relation to the land they owned. The more she could bring, the stronger her case would be.

Despite the biometric technology that had successfully authenticated Gulnar's bodily identity (Cohen 2019), the process of re-verification was contingent upon sources, genealogical and territorial, external to her uniquely biometric identity. More specifically, Gulnar's turn to a genealogical link to the Prophet Muhammad himself, importantly within an official interrogation setting, was a moral strategy intended not only to compel officials to accord her respect but to also serve as a genuine source of identification. If NADRA based its identification on genealogical descent, then in Gulnar's view her declaration of her Sayyid status was within that frame. Her claim represented an attempt at genealogical computation, to create an equivalence, at least momentarily, between herself and an unquestionable, reliable identity. This was not challenged in the interview. Through their evidence-based requirements, and especially in their less than helpful suggestion that Gulnar must know someone in Peshawar if she really was from there, NADRA officials, too, acknowledged the importance of multiple, far-reaching networks.

NADRA required Gulnar to provide documentation of her genealogical links to Pakistan and specifically to Peshawar. She responded with her customary tenacity. She got on a bus to Peshawar almost immediately and "got everything sorted" within a few days. She had to find some kind of documentary proof of her link there. She remembered that her siblings had sold their grandfather's house to another relative, and when she approached them for a copy of the property deed, the cousin said he would give her a thousand copies if she needed them. Gulnar Bibi had a copy printed on stamp paper and presented another copy to me. ${ }^{30}$ The list of documents Gulnar Bibi was told to bring included the shajarah-yi-nasab. Through the property deed she had just acquired, she was able to show that her father had owned property in Peshawar, and before 1978, when the large-scale migration of Afghan refugees into Pakistan had started. However, she was unable to obtain a shajarah-yi-nasab for this property through the revenue department,

29 A "tehsil" is a sub-district, and a union council is the smallest territorial unit of governance. A union councilor is a member elected to this body.

30 Stamp paper of varying amounts (the most common was for Rs.20) was used for affidavits. While the stamp paper original enabled an authentic claim to be reckoned with, at least in theory, people had multiple copies of them to prove the existence of the original. 
likely because, as a woman, she had not been included as one of the inheritors. ${ }^{31}$ In the absence of this source of verified lineage, she successfully deployed another set of approaches and relations that could vouch for her source of descent in multiple ways.

For instance, she needed a letter from the deputy superintendent of police, a man she did not know since she had moved away at a very young age. When she approached him, she told him, "I do not know you, but my father knew your senior Akhtar Gul." She said she had remembered that name in her home as a child, and it had come back to her when she was in Peshawar. She told me that as soon as she mentioned the name the officer wrote her a letter. This letter states that "Gulnar Bibi is an original Pakistani, and I am proud to testify to this." This testimony of an authoritative person, through a personal connection, served to authorize and support Gulnar's claims.

Next, she went to the current union councilor in the neighborhood. Her relatives in Peshawar said he was the son of the neighborhood's kabariya (garbage collector/recycler). "You do not know me, but I know you. I used to throw things at you when you passed as a little boy, then we would both get popsicles. Your father educated you and so now you are here, but don't forget where we both are from." He told Gulnar he would write the letter and that she did not need to bring his father back from the grave. Gulnar Bibi may or may not have been embarrassing him over the fact that his father was a garbage collector; this was suggested but not made explicit. Gulnar made the union councilor remember "who she was"- through the differences between her family and his - ultimately transforming that intimate connection into official recognition.

Lastly, she described how, "When I went back to that office, the NADRA official was staring at me. He said this takes people years at times, but you got it done in a matter of days." The official was not simply remarking on her efficiency or tenacity. Her ability to get this done implied she had the requisite network; relatives and contacts in Peshawar who could verify her connection to her old neighborhood. It was this relatedness, which extended beyond the genealogical while also connecting to it, which authenticated her.

Gulnar Bibi's experience and tactics show that firstly, governmental systems of verifying identity rely on an infrastructure of bureaucratic documentation and the social relations necessary to produce these documents (Rao 2019). In fact, NADRA employees seem to view a person's ability to navigate this system through connections and relations as itself a sign of authentication. Secondly, despite failing to acquire the shajarah-yi-nasab, Gulnar Bibi continued to deploy multiple sources of genealogical connection-such as her father and the union councilor-extending her claims to lineage beyond the

31 See "Record of Rights" in the United Nations Habitat's training manual, Pakistan Settlements Flood Recovery Project: Land and Property Rights in Pakistan (2012: 151). 
strictly textual or biological. As Gulnar Bibi's strategy foregrounds, genealogy, even in a non-documented form, can be instrumentalized and worked into other kinds of documents. In particular, genealogy forms the basis of documents that root Gulnar in a specific place, Peshawar, and establish her as a citizen.

Gulnar comes across as practiced in how she deals with everyone involved, precisely because she is accustomed to obstacles. Yet, for her approach to work, the infrastructure has to be somewhat consistent, even in its breakdowns and ruptures. In short, for genealogical knowledge and governance systems to work in tandem, a certain amount of continuity and established interaction is required. Yet this is not always the case because the state not only changes over time but is also spatially uneven. Gulnar Bibi's card was eventually unblocked, but this is not the case for all, and especially not Pashtuns who hail from the Federally Administered Tribal Areas, which until recently had a "special" administrative structure. Many of them go through not one but multiple interviewing processes. Further, even after meeting documentary requirements and undergoing other verification procedures, many Pashtuns are still waiting for their cards to be unblocked.

The internally differentiated state produces unevenness across regions for how citizens, inter-generationally, develop practices and even habits of approaching the state. In a centralized institution such as NADRA, which aims to standardize its practices across the nation, officials experience friction when they come up against these variegated practices and conceptions. NADRA constantly works on strategies for encompassing this complexity. In the next section I will describe how the tensions generated by such historically uneven governance systems unfold and trace their implications for those who occupy the peripheral space of the carefully constructed frontier. The ways in which precolonial, colonial, and postcolonial regimes historically deployed kinship and genealogical relations on the frontier map onto territorial notions in ways that condition the possibilities for genealogical success and failure. I will explain how NADRA, given its descent-based concerns, opens itself up to polyvocal articulations of genealogical identity that extend beyond the official genealogical record it requires. The friction between the database's architecture and citizens' claims to genealogically reliable personhood can lead to claimant successes like Gulnar Bibi's, or tragic failures.

GENEALOGICAL FAILURE: "MUSAKHEL IS A PLACE BUT IT IS ALSO WHO WE ARE"

During my fieldwork at the NADRA Registration Center, I frequently accompanied a data-entry operator who I will call Ashraf, in the afternoon shift. People came into the "Mega" Registration Center in Islamabad for a number of reasons related to their identity cards: to make corrections, to update their identifying information - for example if they had married, had a child, or changed their address — or 
to make a "fresh" identity card if they did not already have one. Data-entry operators were not career bureaucrats but contractually employed and trained by NADRA, and they came from a variety of professional backgrounds. Ashraf had come to data entry through a circuitous career path. He enjoyed the job, especially the prerogative it gave him to half seriously-half mischievously interrogate the citizen-applicants. A staunch supporter of the current Prime Minister Imran Khan, he once joked with a young woman who had come in to change her address that he would only do it if she promised to vote for Imran Khan. While not malicious, Ashraf was aware of the small powers he held over people.

A young man accompanied by elderly parents and a small child was called up at Ashraf's data-entry station. This man, who I will call Hassan, was twentyeight years old but was registering for a NADRA card for the first time. Initially, Ashraf gave him grief, asking how he, as a responsible adult, could be registering at his late age. Then Ashraf asked him for documentation to prove his age, and Hassan produced a laminated middle school certificate. Ashraf held it up between his thumb and forefinger, sighing exasperatedly, muttering, "Do you see the state of this thing?"

Ashraf asked Hassan if anybody in his family already had an identity card, and Hassan replied that his parents and brothers did. Ashraf looked up the father's record through his identity card number, and finally said, "Your brother's date of birth is 1980. According to the school certificate, you are the same age. Now, you tell me, unless you are twins, is that possible?" The family went to the side and discussed this dilemma in Pashto, counting months and years, listing off other siblings. Ashraf, who did not speak Pashto, yelled at them, "You don't have to get into a fight about it!" They looked confused. Ashraf meanwhile told me he had to be careful in the case of Pathans. He did a background check in NADRA's records for fraud by clicking on a link titled "digital impounding."

Eventually, Hassan returned to Ashraf's desk and told him that his date of birth was in fact 1982. Ashraf sighed, complaining that the lack of proof of the year of birth created such "inefficiencies," but then proceeded with registration. While Ashraf was taking down the permanent address from Hassan's parents' cards - both cards were in front of him- he looked up confused and asked, "What is Musakhel? Is it a district, a street, what is it?" Hassan explained that the family's permanent address was in the tribal agency of Mohmand. Musakhel was the name of their village, but Ashraf could not find this in the drop-down menu of his address library. ${ }^{32}$ "But what is Musakhel?" he asked with annoyance as he scrolled through the names of districts on the drop-down list.

Hassan responded to Ashraf's question by attempting to describe Musakhel in terms of geographical scale. "It is like this whole area: Pindi and Islamabad."

\footnotetext{
${ }^{32}$ NADRA's address library is populated through categories of places drawn from the revenue department. It is possible, given that there was no direct settlement of Mohmand agency until recently, that this village was not included in the library.
} 
Simultaneously, his father told both Hassan and then me that Musakhel was the name of their tribe, using the Urdu word qaum. In an act of complex genealogical computation, making multiple relations equivalent to one, Hassan's father turned to Ashraf and emphatically declared, "Musa was the father of all of us." Musakhel was a place, a person, and a way of signifying genealogical connection. Hassan's father explained that Musa came before his grandfather, and his grandfather's grandfather, and so on. He proceeded to list a number of other names from their genealogy, punctuating each of them with the exclamation "and he was also our father!" 33 Hassan attempted to do some damage control and explained that "Musakhel is a place but also our ancestor."

Ashraf, by this point, was rolling his eyes behind his screen. The thorough explanation of lineage was irrelevant for him. All he wanted was the spatial category that "Musakhel" fell under. At the same time, Ashraf was not unconcerned with who Hassan and his father were in terms of their kin relations. Yet his examination of kinship at this data-entry stage was shallow. Ashraf had asked for Hassan's parents' identity cards, confirming that Hassan was related to them. He had double-checked the dates of birth with Hassan's other siblings. Ashraf was concerned with the immediacy of relatedness to authenticate identity - the authenticity of horizontal kin connection-and not deep, or rather, steeply vertical genealogical details of the sort that he had been provided. Here, the decision to perform genealogical computation came from the citizen-applicants themselves. In particular, the elderly father considered this an important aspect of his identity and thus how he understood an identifiable person to be made. The genealogy represented how he understood himself as well as what had already been recognized and validated by the state, namely that which marked him as from "Musakhel," the place and the link that tied the family to their place of origin in Mohmand.

After the Musakhel confusion, Ashraf led the family to his senior, the assistant manager who sat upstairs. It was clear he had not wanted me to come along, and so I did not follow. A few months later, I ran into Hassan and his father outside the Registration Center. They recognized me, we exchanged greetings, and I asked them whether they had managed to get Hassan's card. In response, Hassan's father flew into a rage. He explained that NADRA had not approved Hassan's application because they claimed he did not have enough proof (sabut). He said, "It should be enough proof that we have lived in Fauji Colony in Islamabad for so many years, that he (Hassan) was born here. They keep asking for more proof, and for documents we do not have."

33 "Places, like persons, have individual identities: they possess proper nouns that others have bestowed upon them" (Ho 2006: 141), yet the problem of duplicate names is acute. As a result, genealogical experts devise ways, such as alphabetization, to systematize biographies on the basis of names themselves rather than places, time, or generation (ibid.: 143). In the case of Musakhel, the place name itself is a means for all belonging to the clan to both identify one another and spatially locate themselves. 
One of these documents was the shajarah-yi-nasab. I asked him whether he could return to Mohmand and get these documents. He explained, "God has given us plenty of land," but it was jointly owned with other family members. Moreover, there was no record of land transfer through generations. In the absence of revenue settlement in the federally administered tribal areas, including during the colonial era, it made sense that this was the case. ${ }^{34}$ Hassan's father emphasized yet again, as he had the first time we met, that this did not mean he was without lineage. He explained that they were Musakhels and that I could go to Mohmand and ask anyone who they were, and they would tell me who Musakhels were. In the absence of documents that could authenticate genealogical ties - authorized or even produced by the state - Hassan's father was unable to "show the work" of genealogical computation, not because it did not exist but because it did not match the requisite form. He could only rely on his own ability to recite his ancestor's names, put forward a deep genealogy, and use tribal affiliation as a means to authenticate citizen identity. I later found that this was not Hassan's first attempt at getting an identity card. He had tried and failed before, as the information he did provide could not definitively determine that he was not Afghan. ${ }^{35}$ While Hassan's failure was partly a function of the blackboxed nature of the technology at hand - the obfuscation of the precise moment at which Hassan's identity registration did not proceed forward-a key point of failure (based on the encounter during registration) rests on the mismatch between genealogical forms.

My conversation with Hassan and his father clarified why the elderly man had been so insistent about orally detailing his lineage that first day at the Registration Center. Since Hassan's family belonged to the tribal agency of Mohmand, and the Mohmand tribe inhabited both sides of the AfghanistanPakistan border, the emphasis on Musakhel was intended to signify that they were on this (Pakistani) side of the border and were thus entitled to an identity card. The presentation of this "real" genealogy was supposed to fill the holes of absent documentation. ${ }^{36}$ Given that Musakhel is a territorially defined subdivision of the Mohmand district in Pakistan, Hassan's father was simultaneously emphasizing a genealogical claim and territorial affiliation.

\footnotetext{
34 The frontier was settled in that the Peshawar valley was brought under colonial revenue administration. However, this land settlement did not extend to the non-agrarian tribal areas (Nichols 2001).

${ }^{35}$ The neighborhood that Hassan and his family lived in also had Afghan residents. Further, the tribal agency they belonged to, Mohmand, was also a tribe that extended across the border into Afghanistan. This generated a problem that could perhaps only be resolved through a genealogical claim that could also be spatially asserted: the place and lineage of Musakhel.

36 Marshall Sahlins offers a useful conceptual tool for understanding kinship: it is the "transmission of life capacities among persons" (2013:29). The reader may have noticed that Hassan's father does a lot of the talking. He is trying to make their lineage work for Hassan, so that his grandchild can be enrolled in school, so that Hassan can get work, and avail the life capacities, broadly conceived, that genealogical success within NADRA's databases allows.
} 
Techniques of governance have long intersected with genealogies, especially in relation to authority and legitimacy, but not always in an even fashion. There are moments when genealogical memory is mobilized but fails, such as in Hassan's encounter with a data-entry operator. In its failure, a conjuncture comes to light: one kind of genealogical understanding and articulation, as a form of social knowledge, reveals itself as misaligned with the mode of governance it intersects. Instead of approaching this as a misunderstanding or misstep, historicizing this dissonance enables insight into how the body politic is fractured, along the lines of historically constituted power differentials. People like Hassan are then perpetually responding to these lines of internal variegation.

\section{TRIBAL GENEALOGIES AND RULE ON THE FRONTIER}

To speak explicitly to the relationship between genealogical failure and territory, the Federally Administered Tribal Areas, where Hassan and his father hail from, were for centuries subjected to a form of frontier governance (Hopkins 2020) distinct from the rest of colonial India. The regions that now constitute most of the tribal areas in Pakistan were considered autonomous and never brought fully into the territory of British India. Until late 2018, the system for preparing revenue records, of the sort described by Baden-Powell in the context of a settled property regime in the Punjab, was mostly absent in the majority of the tribal areas that currently border Afghanistan. ${ }^{37}$

The Pashtun tribal structure, in contrast to Punjab, was fairly well-documented, but this knowledge was used to limit direct control and governance. Ethnographic knowledge produced by colonial officials, which justified the tribal area's "independence" and limited British interference, relied on characterizing Pashtun tribes as ungovernable. ${ }^{38}$ Instead, the colonial approach to governance in the tribal areas was shaped by a romanticized notion of a "seductive and elemental confrontation between British officer and native warrior" (Tripodi 2011: 11). Personal contact and intimate knowledge of the unruly tribesman were considered the most effective ways to manage this region. ${ }^{39}$ In moments when the question arose of annexing tribal areas, which would bring the region directly under British control, ${ }^{40}$ the colonial state decided not to because, unlike Punjab, the tribal areas

37 The exceptions include the Peshawar district, and parts of Kurram Agency, due in large part to the fact that its land can be cultivated.

${ }^{38}$ See the monographs written on frontier tribes by political agents such as Merk (1984[1898]), and Howell (1979[1931]).

39 Along with Tripodi, see Haroon (2007), who argues that the ethnographic rendering of Pashtun tribes' fierce independence was key to the forms of rule they were governed under.

${ }^{40}$ An example is the September 1895 Pamir Boundary Agreement with Russia, which established the international boundaries of Afghanistan. Further, the decision not to directly rule over these areas should not be taken to mean that the frontier was irrelevant to the colonial political economy. On the contrary, this region was a central part of colonial circuits of capital circulation and accumulation, as evidenced by infrastructural development in the area, specifically the Khyber Pass Railway 
were for the most part not an agricultural heartland and thus would be a financial "burden" (Spain 1963: 118).

As described earlier, genealogy was intimately tied to landed property relations in Punjab, and to some extent in the settled districts of other areas such as the Peshawar district, ${ }^{41}$ which came to be the North West Frontier Province. ${ }^{42}$ In the "un-administered" tribal areas, however, genealogical definition was situated along a different set of axes. While in Punjab the tribe was dispersed across villages and possessed minimal indigenous political organization, the frontier tribes were seen to have a cohesive political form and effect through their system of segmentary lineages. ${ }^{43}$ In short, despite the definitional ambiguity of tribe or biradari, ${ }^{44}$ the colonial state in Punjab attempted to define a tighter structure of rule around it through record keeping, documentation, ${ }^{45}$ and administration. ${ }^{46}$

connecting Peshawar to the Afghan border. During these discussions of infrastructural development in the area, colonial officials negotiated tribal hierarchies and centered questions of customary law (Medhi 2020).

${ }^{41}$ A curious aspect of frontier colonial governance was that it did not rely entirely on ethnic differentiation (Nichols 2001). The Peshawar colonial land settlement conformed to the established Punjab model, with some reforms catered to Pashtun tribal society to assert colonial moral authority. As Andre Gunder Frank (1992) shows, the move from nomadism to settlement was not a transitional, historical move. Rather, specialized pastoralism was likely a reaction to ecological and economic exigencies by agricultural peoples who had once been settled. Nichols draws on these insights to challenge the settled and tribal distinction in the Pashtun context. While the distinction is far from binary, the administrative structures it led to in turn shaped varying levels of imperial influence and effects.

${ }^{42}$ Colonial officials like Tupper found kinship, not caste, to be the operational category of social organization in Punjab. This did not mean that hierarchy, or "caste," did not exist. Rather, its presence was irregular and inconsistent. For a discussion of caste amongst Indian Muslims, see Lindholm (1985).

43 On segmentary lineage, see Dresch 1986. In addition, even as the agricultural frontier was extended from the Punjab to areas such as Peshawar or Kurram, the unevenness of the colonial documentary regime (specifically around property relations and revenue) was in part a function of the ways in which the colonial state differentiated between inhabitants of the plains and upland areas. In other words, where revenue settlement did take place, the social and political structure of the tribe was reflected in land and revenue policy (represented in discussions of Yusufzai qualities in the settlement of the Peshawar Valley), but in non-agrarian areas, the tribe was the source of political authority, particularly for adjudicating disputes between tribes or with the colonial state itself. In his study Ruling the Savage Periphery (2020), Hopkins views this unevenness in colonial rule functioned as a form of "sovereign pluralism" that incorporated native autonomy in ways central to colonial power.

44 A descent group, according to Hamza Alavi (1972) is a collection of households related through patrilineal kinship, where links of common descent can be traced in the paternal line regardless of the number of generations. Yet, this term sat uncomfortably with other terms used alongside it, such as qaum (nation) or zaat (sub-caste).

45 Such records were included in the village record of rights known as the wajib-ul-arz. After 1873 , they were compiled into separate volumes, or rivaj-i-aam. These were prepared through oral questionnaires posed to local gatherings of influential tribal or village leaders.

46 David Gilmartin explains how the British "by their very nature of their position as culturally alien rulers, could make little claim to legitimate authority on the basis of religion" (2014: 6). They could, however, use customary law to structure their rule. 
In contrast, and perhaps counterintuitively, "tribe" had a far more specific meaning and purpose in the absence of regular government on the frontier. The explicit overlap between governance strategies and ethnographic knowledge about tribes in the making of the frontier illustrate, as Sana Haroon argues (2007), that the region's demarcation as semi-autonomous (outside of "settled India") was a sociological one. Colonial engagement with the ethnographic notion of the tribe informed both colonial governance on the frontier and the forms and value of genealogical knowledge. In turn, colonial textual representations and solicitations of genealogical information likely affected tribal conceptions of their own genealogy-based identity (Lindholm 1996). Thus, the colonial government shaped the motivations for tribal groups themselves to subsequently take up genealogy (Haroon 2016) and the means by which they did so. The intersection of tribal genealogy, ethnographic knowledge, and colonial governance on the frontier, unlike in the Punjab, reveals how the meanings of genealogy and tribal affiliation were concretized in ways that, through their very dissonance, continue to resonate in interactions like that between Hassan's father and Ashraf the data-entry operator.

Even in areas where direct colonial rule (including, crucially, revenue settlement) was absent, frontier tribes and their genealogical formations were hardly left alone (Beattie 2002; Tripodi 2011). Self-consciously distinct from the rest of British India, "regular government" on the frontier was replaced by a system of officers concerned with managing the area as a critical geopolitical space for the security of colonial territory. This included interactions with the Afghan government across the border as well as Russian imperial interests (Simpson 2015), which meant crafting a system to manage the "troublesome" tribes on the frontier. Here, tribal genealogy was deployed copiously to codify legal and judicial actions against tribes.

NADRA's demands for the shajarah-yi-nasab reflect these prior administrative formations. In Punjab, genealogical documentation was driven by the idea that tribal lineages mapped onto agricultural land. On the frontier, tribal genealogy was instrumentalized to produce the space as a frontier-a geopolitical buffer for imperial interests - as opposed to a settled place of belonging. As a result, the "tribe" in the colonial imagination was always more than a set of genealogical and social relations on the frontier: it was a form of political organization that had to be dealt with politically. Frontier tribal genealogy came to be deployed for signaling reputations, and alliances (albeit shifting ones), and for signifying political stakes for groups in relation to border zones. ${ }^{47}$ In this instance, the genealogical computations informing tribal governance were not

\footnotetext{
47 For instance, the colonial state in India enumerated fighting strength according to tribe and understood capacity as a function of the integrity of the tribal structure. See India Office Records, Military, 1916-1920, IOR/L/MIL/7/7199.
} 
reified within a documentary process of making claims or proving identity, particularly in relation to settled land and territory.

It is this tribal genealogical imagination that, for both "tribal" Pashtuns and government officials, intersects with the contemporary Pakistani security state. The colonial state's concern with tribal genealogy on the northwest frontier was primarily a function of security rather than revenue. Such a colonial state of security on the frontier set into motion a system of governance-alongside practices for how tribes learned to interact with this particular governmental form through political agents - that continues to produce dissonance between citizens and the state in the postcolony, especially when residents of tribal areas move to places like Islamabad. ${ }^{48}$

I argue that NADRA's identification practices fold in genealogical conceptions that are tied to land and documentation, as they function as evidentiary sources of individual identity. NADRA is somewhat flummoxed, however, when a "deep" genealogy is brought in as proof. The nature of a deep genealogical claim, for instance Gulnar Bibi's link to the Prophet Muhammad as an already legitimatized identity, complicates NADRA's process of establishing specific links, since NADRA'S ability to record descent-based relations builds upon colonial documentary regimes.

While NADRA incorporates the ongoing system of political officers on the frontier to authorize connections to tribal people, and while it seeks alternative means of documentation, it constantly comes up against problematic ambiguities when dealing with the identities of tribal Pashtuns. NADRA is faced with a limited form of documentation, a result of the uneven state of government I have described. Moreover, and more significant to our purpose here, when NADRA asks, "Who are you?" residents of the tribal agencies are forced to take on this burden of proof differently from people of other areas. In response, they articulate genealogies whose meanings lie outside of what the technocratic postcolonial state is demanding. As I have argued, this should not be read as a simple misunderstanding. Rather, it is borne out of a rehearsed relation where one's genealogy has held a particular meaning in relation to one kind of security state (the colonial one) and is now asked to take on another. During my fieldwork, shajarahs were often recited. When I asked my interlocutors if they had a genealogical document, the answer would never be a simple yes or no. It would always be, "Of course, we have a shajarah," followed by a recitation of one, or at least the names of a few ancestors and places. The simple fact of the lack of documentation, a source of ambiguity that potentially questions the legitimacy of

\footnotetext{
48 One iteration of this is the Pashtun Tahaffuz Movement (Movement for the Protection of Pashtuns). It was sparked by the police murder of Naqeebullah Mehsud in Karachi, one of many justified under counter-terrorism measures. This movement calls out the state of exception in the tribal areas as one reason for state violence.
} 
lineage and belonging itself, produces a need to reassert one's genealogy, affirming the value of its existence.

\section{CONCLUSION}

In a similar vein, Ma'i Dada's emphasis on the value of genealogical expertise, alongside loud proclamations about his own status as a Pashtun, hint toward an identity in crisis. Genealogies become significant in times of need. Throughout Khan's story, there are oblique references to the murkiness of Ma'i Dada's own shajarah, and Hindu dhobis claim that he is not a Pashtun at all but an uncircumcised Hindu. When the author accidentally stumbles upon the truth of this rumor, he is deeply conflicted. What does this mean for his family, the entire clan of Mirzakhels, if Ma'i Dada who taught them who they were, was in fact not who they thought he was?

As the truth of his genealogical origins is discovered, Ma'i Dada, nearing the end of his life, experiences a mixture of resignation and despair. "Oh, well — a teli's son will always be a teli's son. He doesn't become a Pathan even if Pathans have reared him" (Khan 1998: 256). Ma'i Dada's words, and the author's conflict about his discovery, bring to the surface tensions that lie at the heart of genealogical processes and relations. Again, Ma'i Dada shows us when and how genealogical claims become important to assert.

Much like in Khan's story, in the contemporary context of internal displacement from tribal areas to cities such as the fortified capital of Islamabad, tribal Pashtun families struggle to re-establish the legitimacy of their genealogies. They attempt to make themselves visible as holders of authentic genealogies - fractured as these claims might be through the troubled experiences of migration and colonial pasts - in the hopes that this will translate into holding an authenticated identity. It is in this context that deep genealogies come to the surface. The need to practice and excel at genealogical computation is generated out of the experience of not having a verified identity document, producing anxiety about the legitimacy of belonging to the here and now, and how one is seen by an outsider, especially the state. What people like Gulnar Bibi or Hassan and his father present to the state is a sense of the genealogically authenticated person, informed at least in part by a history of colonial ethnographic knowledge production. Yet, in the absence of official documentation, which is also a function of colonial history, what other means of assuring genealogical success do they have?

The relationship between genealogical claims and evidentiary sourcesbetween truth and documentary proof - is fraught not only because of complex forms of social organization but also because of how governments deploy genealogical information, producing exceptions layered within historically uneven power relations. While the colonial and postcolonial states' intersection with genealogical matters significantly informs the latter, their effects 
are not unilateral. The difficulty of managing or stabilizing genealogies - a quality that in fact creates the need for expertise - means that there are leakages and unexpected turns, ranging from forgotten relatives to marriages between refugees and nationals, within the genealogical tree and even in NADRA's database.

At the very end of Khan's story, the author's father, who likely already knew this secret of Mai' Dada's identity, makes a vital intervention. He creates an opening through which Ma'i Dada, even as a teli, can be accepted. Yet, Khan's realization and appreciation of the role that an outsider played in the formation of the family's identity is coupled with the need to deny and erase Ma'i Dada's outsider status. In this sense, the Pashtun migrants with whom I am engaged are involved in a form of genealogical computation that is not only reworking the past to bring it into the present - be it an ancestor (Musa) or an old neighborhood friend - in order to remake and reassert themselves in a new context. They are also deploying genealogical relations to build and nurture kin relations to enable movement into the future. The author's father's last words to him about Ma'i Dada in this regard might elucidate this:

Whoever he was, he loved you and wanted you to learn to live with honor and dignity like your forebears. And that's what you should remember. Understand? Now, go play." Then, just as he had started to move, he broke his stride, turned around and snapped angrily, "And listen, don't let any son-of-a-bitch tell you he wasn't a Muslim! Don't let anyone say he wasn't a Pathan!" (Khan 1998: 256).

\section{REFERENCES}

Abraham, Itty. 2018. Prehistory of Aadhaar: Body, Law, and Technology as Postcolonial Assemblage. East Asian Science, Technology and Society 12, 4: 377-92.

Abu-Lughod, Lila. 1986. Veiled Sentiments: Honor and Poetry in a Bedouin Society. Berkeley: University of California Press.

Ahmed, Akbar S. 1976. Millennium and Charisma among Pathans: A Critical Essay in Social Anthropology. London: Routledge and Kegan Paul.

Alavi, Hamza A. 1972. Kinship in West Punjab Villages. Contribution to Indian Sociology 6, 1: 1-27.

Anwar, Nausheen. 2013. Negotiating New Conjunctures of Citizenship: Experiences of 'Illegality' in Burmese-Rohingya and Bangladeshi Migrant Enclaves in Karachi. Citizenship Studies 17, 3-4: 414-28.

Baden-Powell, B. H. 1892. Land Systems of British India, Volume II, Book III: The System of Village or Mahal Settlements. Oxford: Clarendon Press.

Barth, Fredrik. 1965. Political Leadership among Swat Pathans. London: University of London, Athlone Press. 
Beattie, Hugh. 2002. Imperial Frontier: Tribe and State in Waziristan. Richmond, Surrey: Curzon.

Benhabib, Seyla. 2004. The Rights of Others: Aliens, Residents and Citizens. Cambridge: Cambridge University Press.

Bhattacharya, Neeladri. 2018. The Great Agrarian Conquest: The Colonial Reshaping of a Rural World. Ranikhet: Permanent Black in association with Ashoka University.

Bouquet, Mary. 1996. Family Trees and Their Affinities: The Visual Imperative of the Genealogical Diagram. Journal of the Royal Anthropological Institute 2, 1: 24-56.

Chatterjee, Partha. 2011. Lineages of Political Society: Studies in Postcolonial Democracy. New York: Columbia University Press.

Cohen, Lawrence. 2019. The 'Social' De-Duplicated: On the Aadhaar Platform and the Engineering of Service. South Asia: Journal of South Asian Studies 42, 3: 482-500.

Das, Veena. 2019. The Signature of the State: The Paradox of Illegibility. In Life and Words. Berkeley: University of California Press, 162-83.

Dresch, Paul. 1986. The Significance of the Course Events Take in Segmentary Systems. American Ethnologist 13, 2: 309-24.

Dresch, Paul. 1988. Segmentation: Its Roots in Arabia and Its Flowering Elsewhere. Cultural Anthropology 3, 1: 50-67.

Edwards, Jeanette and Marilyn Strathern. 2000. Including Our Own. In Janet Carsten, ed., Cultures of Relatedness: New Approaches to the Study of Kinship. Cambridge: Cambridge University Press, 149-67.

Evans-Pritchard, E. E. 1969. The Nuer: A Description of the Modes of Livelihood and Political Institutions of a Nilotic People. New York: Oxford University Press.

Feeley-Harnik, Gillian. 2013. Placing the Dead: The Kinship of Free Men in Pre- and Post-Civil War America. In Susan McKinnon and Fenella Cannell, eds., Vital Relations: Kinship and the Critique of Modernity. Santa Fe: SAR Press, 179-216.

Feldman, Ilana. 2007. Difficult Distinctions: Refugee Law, Humanitarian Practice, and Political Identification in Gaza. Cultural Anthropology 22, 1: 129-69.

Frank, Andre Gunder. 1992. The Centrality of Central Asia. Studies in History 8, 1: 43-98.

Franklin, Sarah and Susan McKinnon. 2011. Relative Values: Reconfiguring Kinship Studies. Durham: Duke University Press.

Fritzsche, Peter. 2008. Life and Death in the Third Reich. Cambridge: Harvard University Press.

Gates, Kelly. 2011. Our Biometric Future: Facial Recognition Technology and the Culture of Surveillance. New York: NYU Press.

Gilmartin, David. 2014. Civilization and Modernity: Narrating the Creation of Pakistan. New Delhi: Yoda Press.

Grossberg, Michael. 1985. Governing the Hearth: Law and the Family in NineteenthCentury America. Chapel Hill: University of North Carolina Press.

Haroon, Sana. 2007. Frontier of Faith: Islam in the Indo-Afghan Borderland. New York: Columbia University Press.

Haroon, Sana. 2016. Competing Views of Pashtun Tribalism, Islam, and Society in the Indo-Afghan Borderlands. In Nile Green, ed., Afghanistan's Islam: From Conversion to the Taliban. Berkeley: University of California Press, 145-62.

Ho, Engseng. 2006. The Graves of Tarim: Genealogy and Mobility across the Indian Ocean. Berkeley: University of California Press. 
Hopkins, Benjamin. 2020. Ruling the Savage Periphery: Frontier Governance and the Making of the Modern State. Cambridge: Harvard University Press.

Howell, Evelyn Berkeley. 1979[1931]. Mizh: A Monograph on Government's Relations with the Mahsud Tribe. Repr. Oxford: Oxford University Press.

Khan, Asad Muhammad. 1998. Ma'i Dada. Muhammad Umar Memon, trans. Annual of Urdu Studies. Center for South Asia, University of Wisconsin-Madison. Vol. 13, 243-26. (First published in كهركى بهر آسمان, Ilqa Publications, Lahore, 1982.)

Khoja, Neelam. 2020. Competing Sovereignties in Eighteenth-Century South Asia: Afghan Claims to Kingship. Journal of the Economic and Social History of the Orient 63, 4: 555-81.

Lambek, Michael. 2011. Kinship as Gift and Theft: Acts of Succession in Mayotte and Ancient Israel. American Ethnologist 38, 1: 2-16.

Lindholm, Charles. 1985. Paradigms of Society: A Critique of Theories of Caste among Indian Muslims. European Journal of Sociology 26, 1: 131-41.

Lindholm, Charles. 1996. Frontier Perspectives: Essays in Comparative Anthropology. Karachi and New York: Oxford University Press.

Magnet, Shoshana. 2011. When Biometrics Fail: Gender, Race, and the Technology of Identity. Durham: Duke University Press.

Maine, Henry. 1861[1931]. Ancient Law. New York: J. M. Dent \& Sons.

McKinnon, Susan and Fenella Cannell, eds. 2013. Vital Relations: Kinship and the Critique of Modernity. Santa Fe: SAR Press.

Medhi, Abhilash. 2020. Infrastructural Contingencies and Contingent Sovereignties on the Indo-Afghan Frontier. Modern Asian Studies 54, 6: 1949-86.

Merk, W.R.H. 1984[1898]. The Mohmands. Repr. Lahore: Vanguard Books.

Moore, Annelis. 2003. Migrant Domestic Workers: Debating Transnationalism, Identity Politics, and Family Relations. A Review Essay. Comparative Studies in Society and History 45, 2: 386-94.

Nayyar, Adam. 2000. Punjab. In Alison Arnold, ed., The Garland Encyclopedia of World Music, Volume 5, South Asia: The Indian Subcontinent. New York: Garland Publishing.

Niamatullah. The History of the Afghans. 1613-1630[1829]. Bernhard Dorn, trans. London: Oriental Translation Fund Publications.

Nichols, Robert. 2001. Settling the Frontier: Land, Law and Society in the Peshawar Valley, 1500-1900. Karachi: Oxford University Press.

Petryna, Adriana and Karolina Follis. 2015. Risks of Citizenship and Fault Lines of Survival. Annual Review of Anthropology 44: 401-17.

Ramaswamy, Sumathi. 2010. The Goddess and the Nation: Mapping Mother India. Durham: Duke University Press Books.

Rao, Ursula. 2019. Population Meets Database: Aligning Personal, Documentary and Digital Identity in Aadhaar-Enabled India. South Asia: Journal of South Asian Studies 42, 3: 537-53.

Rose, Horace Arthur. 1970[1914]. A Glossary of the Tribes and Castes of the Punjab and North-West Frontier Province. Vol. 3. Lahore: Superintendent, Government Printing, Punjab. At: https://archive.org/details/b2901086x_0003 (last accessed 5 Apr. 2021).

Sahlins, Marshall. 2013. What Kinship Is—and Is Not. Chicago: University of Chicago Press. 
Samin, Nadav. 2015. Of Sand or Soil: Genealogy and Tribal Belonging in Saudi Arabia. Princeton: Princeton University Press.

Schneider, David M. 1984. A Critique of the Study of Kinship. Ann Arbor: University of Michigan Press.

Shah, A. M. and R. G. Shroff. 1959. The Vahivanca Barots of Gujarat: A Caste of Genealogists and Mythographers. In Milton Singer, ed., Traditional India: Structure and Change. Philadelphia: American Folklore Society, 40-70.

Shryock, Andrew. 1997. Nationalism and the Genealogical Imagination: Oral History and Textual Authority in Tribal Jordan. Berkeley: University of California Press.

Simpson, Thomas. 2015. Bordering and Frontier-Making in Nineteenth-Century British India. Historical Journal 58, 2: 513-42.

Smith, Richard Saumarez. 1985. Rule by-Records and Rule-by-Reports: Complementary Aspects of the British Imperial Rule of Law. Contributions to Indian Sociology 19: $153-76$.

Spain, James. 1963. The Pathan Borderland. Columbia University, Publications in Near and Middle East Studies. The Hague: Mouton.

Spencer, Herbert. 1893. The Principles of Sociology. New York: D. Appleton and Co.

Tandon, Prakash. 1961. Punjabi Century, 1857-1947. New York: Harcourt, Brace \& World.

Tönnies, Ferdinand. 1887[2001]. Community and Society (Gemeinschaft and Gesellschaft). Cambridge: Cambridge University Press.

Torpey, John. 2000. The Invention of the Passport: Surveillance, Citizenship, and the State. Cambridge: Cambridge University Press.

Trautmann, Thomas. 2001. The Whole History of Kinship Terminology in Three Chapters: Before Morgan, Morgan, and after Morgan. Anthropological Theory 1:268-87.

Tripodi, Christian. 2011. Edge of Empire: The British Political Officer and Tribal Administration on the North-West Frontier, 1877-1947. Farnham: Ashgate Publishing.

Tupper, Charles Lewis. 1881. Punjab Customary Law. Calcutta: Office of the Superintendent of Government Printing.

Weston, Kath. 2001. Kinship, Controversy, and the Sharing of Substance: The Race/Class Politics of Blood Transfusion. In Sarah Franklin and Susan McKinnon, eds., Relative Values: Reconfiguring Kinship Studies. Durham: Duke University Press, 147-74.

World Bank. 1999. Pakistan-Agricultural Taxation in Pakistan (English). Washington, D.C.: World Bank. At: http://documents.worldbank.org/curated/en/ 645411468758398442/Pakistan-Agricultural-taxation-in-Pakistan (last accessed 9 Apr. 2021).

Yanagisako, Sylvia. 2015. Kinship: Still at the Core. HAU: Journal of Ethnographic Theory 5, 1: 489-94.

Zamindar, Vazira. 2007. The Long Partition and the Making of Modern South Asia: Refugees, Boundaries, Histories. New York: Columbia University Press. 
Abstract: In 2016, the National Database and Registration Authority (NADRA), which produces Pakistan's biometric-based national identity card, publicly announced that it would be "re-verifying" identity cards for a national security drive. NADRA relies on the documentation of descent-based relations, including genealogical charts (shajarah-yi-nasab), for its verification procedures. In so doing, NADRA asks the difficult question of who belongs where and who is a citizen, based on who they used to be. This article historically traces the movement of genealogies between the realm of the familial and the bureaucratic. I examine how the colonial state deployed genealogical expertise and how this formation folds into the postcolonial present in ways that shape capacities for genealogybased claims to identity. It demonstrates how what I term "genealogical computation" extends beyond the domain of governance into articulations of identity that seek to establish status, reliability, and trustworthiness. I argue that "reliable persons" are produced in contemporary Pakistan through an encounter between the genealogical computations of citizens and the expectations of an ethno-securitized state. This encounter is borne out of a rehearsed relation where one's genealogy, which has held a particular meaning in relation to one kind of security state (the colonial), is now asked to take on another.

Key words: biometrics, genealogy, governance, identification, kinship, Pakistan, security 